\title{
Leisure Involvement Level of 40 and Over Aged Individuals
}

\author{
Nurullah Emir Ekinci (Corresponding author) \\ School of Physical Education and Sport \\ Hatay Mustafa Kemal University, Hatay, Turkey \\ Tel: 90-554-799-9093Ｅ-mail: ekinciemir@gmail.com \\ Hilal Yalcin \\ Faculty of Sport Science \\ Sakarya University of Aplied Science, Sakarya, Turkey \\ E-mail: hilalylcn4@gmail.com
}

Received: October 20, 2019 Accepted: November 18, 2019

Published: November 27, 2019

doi:10.5296/jei.v5i2.15683ＵRL: https://doi.org/10.5296/jei.v5i2.15683

\begin{abstract}
This study aimed to investigate the leisure involvement level of individuals 40 years and over according to various variables. The study sample consisted of 106 volunteers aged 40 years and over in Hendek district of Sakarya city. As a data collection tool "leisure involvement scale" which developed by Kyle et al. (2007) and adapted to Turkish by Gürbüz et al. (2015), and personal information form were used. SPSS statistic program was used to analyze the data. The histograms, Skewness, and Kurtosis values (between -1 and +1 ) were checked to ensure normal distribution of the data. Therefore, parametric tests, independent sample $t$ tests, and one-way ANOVA tests were used. To determine the significant differences between the groups, the Tukey test used. According to the findings of the study, between the gender variable and social relationship level, between the long-term accommodation place variable and attractiveness, between giving the importance and social relationship, between daily leisure time and giving importance and social relationship level, difficulty in finding free time and attractiveness, between the variables giving importance, social relationship and identification and doing sport statistically meaningful result found with the attractiveness dimension. As a result, it was found that the social relationships of females were higher in
\end{abstract}


leisure time involvement than males. Also, results show that living in the same accommodation place for the long-term effects individuals' leisure time involvement level. It was determined that the time devoted to leisure time affects the importance of leisure time and social relationships positively.

Keywords: Leisure time, Involvement, Adults

\section{Introduction}

Nowadays, with the development of technology, the shape of social life has changed; this change has revealed different human needs. As a result of modern technology, the need for workforce reduced, and the leisure time for humans increased. Leisure activities and physical activity play an essential role in our lives (Heo et al., 2010; Keskin \& Bayram, 2018) and with the evaluation of the free time; it is known that participating to the leisure activities (art, sport activities, etc.) keep the person mentally, spiritually and physically fit (Eskiler \& Karakaş, 2017). It is stated that leisure activities have positive effects on individuals such as social relations, physical and psychological health (Chang, 2016). It can be said that the societies that realize this situation are in various quests to evaluate their free time positively (Aydın \& Yaşartürk, 2016). The most important of these quests is to evaluate the time of individuals by doing sports activities. Many studies have reported that leisure activities are essential for sports activities (Escaron et al., 2019; Ayhan et al., 2018; Ekinci et al., 2019; Berlin et al., 2018). The adaptation of people to changes in the increase of leisure time, simplifying their lives, extending their life span and made more significant contributions to increase their enjoyment of life by giving them more time (Mansuroğlu, 2002).

Therefore, the societies that realize the benefit of this situation try to do different searches in order to evaluate free time positively. This need showed the importance of recreational involvement (Yetim, 2014). According to Üstün et al. (2013) there are several factors that influence the participation of people to free-time activities. Yalçın et al. (2017) stated that leisure involvement is changeable according to gender, women are more interested in self-development and artistic activities, although men are interested in competitive activities that increase their success level and improve their social status.

Leisure involvement is most often conceptualized as a multifaceted construct. Numerous studies suggest that level of leisure involvement is positively linked to activity and equipment knowledge, frequency of participation, the intensity of participation, duration of participation, and opinion leadership (Havitz et al., 2013). Although many researchers from different countries carried out various studies in this field (Havitz \& Dimanche, 1999; Lee \& Graefe, 2002; Kontogianni, 2011; Tachis \& Tzetzis, 2015), but in Turkey, there are not many studies about leisure involvement. That is why we had to motivation to do this study first, we believe that it will make useful contributions to the field and second, we will have an idea about the people aged 40 and over and their attitudes about leisure involvement. 


\section{Method}

\subsection{Study Design}

In the study, a cross-sectional method used as study design, and according to Gratton and Jones (2010) this method is perhaps the most commonly used method in social and sport based studies. According to this method, the data obtained from a sampling group relationship is identified and generalized back to the population.

\subsection{Study Sample}

The study sample consisted of 106 volunteers aged 40 years and over in Hendek district of Sakarya city.

\subsection{Data Collection Tools}

In this study as a data collection tool "Leisure Involvement Scale" (LIS) which was developed by Kyle, Absher, Norman, Hammitt, and Jodice (2007) to measure the involvement level of leisure participants. Adapted to Turkish society by Gürbüz et al. (2015). Leisure Involvement Scale; has 15-item LIS includes three items meant to capture each of five enduring dimensions of leisure involvement — attraction (e.g., physical activity is one of the most enjoyable things I do); centrality (e.g., I find a lot of my life is organized around physical activity); social bonding (e.g., most of my friends/family are physically active); identity expression (e.g., that I participate in physical activity says a lot about who I am); and identity affirmation (e.g., I identify with the people and image associated with physical activity). Each item was rated on a 5-point scale ranging from strongly disagree (1) to strongly agree (5).

A secure sampling method was used for data collection. While the measurement tools applied, the information given about the purpose and importance of the research, and there was no pressure on the participants. The scale was applied by using face to face questionnaire technique.

\subsection{Data Analysis}

SPSS statistic program was used to analyze the data and frequency (f), and the percentage (\%) distributions of the variables were calculated. Skewness and kurtosis were checked to determine whether the data showed normal distribution, skewness, and kurtosis are considered -1 to +1 (Büyüköztürk, 2011). According to skewness and kurtosis results, parametric tests, independent sample $t$ test, and one-way ANOVA test were used. The Tukey test was used to determine the differences between the groups' margin level of error was taken as $\mathrm{p}<0.05$. In the study, the overall Cronbach's alpha number of the scale was found to be 0.82 . The Cronbach's alpha number for the sub-dimensions was found to be between 0.65 and 0.72 .

\section{Results}

In this section, the participants' gender, age, long-term accommodation place, daily free time, the difficulty in finding free time and the status of doing sports were analyzed with the 
sub-dimensions of the leisure involvement scale to find statistical differences.

Table 1. T test results according to gender variable

\begin{tabular}{|c|c|c|c|c|c|c|}
\hline Sub-dimensions & Gender & $\mathrm{n}$ & $\bar{X}$ & $\mathrm{Sd}$ & $\mathrm{t}$ & $\mathrm{p}$ \\
\hline \multirow{2}{*}{ Attraction } & Male & 67 & 2.78 & .95 & \multirow{2}{*}{-1.451} & \multirow{2}{*}{.150} \\
\hline & Female & 39 & 3.04 & .85 & & \\
\hline \multirow{2}{*}{ Centrality } & Male & 67 & 3.54 & .83 & \multirow{2}{*}{-1.328} & \multirow{2}{*}{.187} \\
\hline & Female & 39 & 3.76 & .79 & & \\
\hline \multirow{2}{*}{ Social Bonding } & Male & 67 & 3.37 & .78 & \multirow{2}{*}{-2.245} & \multirow{2}{*}{$.027 *$} \\
\hline & Female & 39 & 3.74 & .84 & & \\
\hline \multirow{2}{*}{ Identity Expression } & Male & 67 & 3.54 & .81 & \multirow{2}{*}{-1.069} & \multirow{2}{*}{.287} \\
\hline & Female & 39 & 3.72 & .82 & & \\
\hline \multirow{2}{*}{ Identity Affirmation } & Male & 67 & 3.54 & .78 & \multirow{2}{*}{-.244} & \multirow{2}{*}{.807} \\
\hline & Female & 39 & 3.58 & .82 & & \\
\hline
\end{tabular}

Note. $* \mathrm{p}<0.05$.

When Table 1 was examined, a statistically significant difference was found between the gender variable and the social relationship sub-dimension of the participants in favor of women $(\mathrm{p}<0.05)$. There were no differences in other sub-dimensions. 
Table 2. ANOVA test results according to the age variable

\begin{tabular}{|c|c|c|c|c|c|c|}
\hline Sub-dimensions & Age & $\mathrm{n}$ & $\bar{X}$ & $\mathrm{Sd}$ & $\mathrm{F}$ & $\mathrm{p}$ \\
\hline \multirow{4}{*}{ Attraction } & $40-44$ & 45 & 3.02 & .87 & \multirow{4}{*}{1.381} & \multirow{4}{*}{.256} \\
\hline & $45-49$ & 27 & 2.65 & .79 & & \\
\hline & $50+$ & 34 & 2.85 & 1.05 & & \\
\hline & Total & 106 & 2.87 & .92 & & \\
\hline \multirow{4}{*}{ Centrality } & $40-44$ & 45 & 3.64 & .71 & \multirow{4}{*}{.623} & \multirow{4}{*}{.539} \\
\hline & $45-49$ & 27 & 3.48 & .92 & & \\
\hline & $50+$ & 34 & 3.72 & .88 & & \\
\hline & Total & 106 & 3.62 & .82 & & \\
\hline \multirow{4}{*}{ Social Bonding } & $40-44$ & 45 & 3.54 & .82 & \multirow{4}{*}{.225} & \multirow{4}{*}{.717} \\
\hline & $45-49$ & 27 & 3.40 & .75 & & \\
\hline & $50+$ & 34 & 3.55 & .88 & & \\
\hline & Total & 106 & 3.51 & .82 & & \\
\hline \multirow{4}{*}{ Identity Expression } & $40-44$ & 45 & 3.58 & .93 & \multirow{4}{*}{.064} & \multirow{4}{*}{.910} \\
\hline & $45-49$ & 27 & 3.59 & .51 & & \\
\hline & $50+$ & 34 & 3.66 & .87 & & \\
\hline & Total & 106 & 3.61 & .82 & & \\
\hline \multirow{4}{*}{ Identity Affirmation } & $40-44$ & 45 & 3.61 & .89 & \multirow{4}{*}{.105} & \multirow{4}{*}{.847} \\
\hline & $45-49$ & 27 & 3.51 & .64 & & \\
\hline & $50+$ & 34 & 3.53 & .77 & & \\
\hline & Total & 106 & 3.56 & .79 & & \\
\hline
\end{tabular}

When Table 2 was examined, no significant difference was found between the age variable and leisure time involvement sub-dimensions $(\mathrm{p}>0.05)$. 
Table 3. ANOVA test results according to long-term accommodation place

\begin{tabular}{|c|c|c|c|c|c|c|c|}
\hline Sub-dimensions & $\begin{array}{l}\text { Long-term } \\
\text { accommodation }\end{array}$ & $\mathrm{n}$ & $\overline{\mathrm{X}}$ & Ss & $\mathrm{F}$ & $\mathrm{p}$ & Difference \\
\hline \multirow{5}{*}{ Attraction } & ${ }^{\mathrm{a}}$ Village & 10 & 2.67 & .83 & \multirow{5}{*}{5.585} & \multirow{5}{*}{$.001 * *$} & \multirow{5}{*}{$b-d$} \\
\hline & ${ }^{\mathrm{b}}$ District & 72 & 2.69 & .85 & & & \\
\hline & ${ }^{\mathrm{c}}$ Province & 10 & 3.37 & .85 & & & \\
\hline & ${ }^{\mathrm{d}}$ Metropolis & 14 & 3.60 & .96 & & & \\
\hline & Total & 106 & 2.87 & .92 & & & \\
\hline \multirow{5}{*}{ Centrality } & ${ }^{\mathrm{a}}$ Village & 10 & 3.00 & .97 & \multirow{5}{*}{5.892} & \multirow{5}{*}{$.001 * *$} & \multirow{5}{*}{ a-c.d } \\
\hline & ${ }^{\mathrm{b}}$ District & 72 & 3.54 & .78 & & & \\
\hline & ${ }^{\mathrm{c}}$ Province & 10 & 4.13 & .63 & & & \\
\hline & ${ }^{\mathrm{d}}$ Metropolis & 14 & 4.12 & .64 & & & \\
\hline & Total & 106 & 3.62 & .82 & & & \\
\hline \multirow{5}{*}{ Social Bonding } & ${ }^{\mathrm{a}}$ Village & 10 & 3.37 & .71 & \multirow{5}{*}{3.176} & \multirow{5}{*}{$.027^{*}$} & \multirow{5}{*}{$\mathrm{a}-\mathrm{c}$} \\
\hline & ${ }^{\mathrm{b}}$ District & 72 & 3.38 & .79 & & & \\
\hline & ${ }^{\mathrm{c}}$ Province & 10 & 3.97 & .71 & & & \\
\hline & ${ }^{\mathrm{d}}$ Metropolis & 14 & 3.93 & .92 & & & \\
\hline & Total & 106 & 3.51 & .82 & & & \\
\hline \multirow{5}{*}{ Identity Expression } & ${ }^{\mathrm{a}}$ Village & 10 & 3.20 & .80 & \multirow{5}{*}{1.319} & \multirow{5}{*}{.272} & \multirow{5}{*}{-} \\
\hline & ${ }^{\mathrm{b}}$ District & 72 & 3.61 & .81 & & & \\
\hline & ${ }^{\mathrm{c}}$ Province & 10 & 3.90 & .39 & & & \\
\hline & ${ }^{\mathrm{d}}$ Metropolis & 14 & 3.69 & 1.04 & & & \\
\hline & Total & 106 & 3.61 & .82 & & & \\
\hline \multirow{5}{*}{ Identity Affirmation } & ${ }^{\mathrm{a}}$ Village & 10 & 3.50 & .63 & \multirow{5}{*}{.201} & \multirow{5}{*}{.895} & \multirow{5}{*}{-} \\
\hline & ${ }^{\mathrm{b}}$ District & 72 & 3.53 & .74 & & & \\
\hline & ${ }^{\mathrm{c}}$ Province & 10 & 3.67 & .52 & & & \\
\hline & ${ }^{\mathrm{d}}$ Metropolis & 14 & 3.67 & 1.22 & & & \\
\hline & Total & 106 & 3.56 & .79 & & & \\
\hline
\end{tabular}

Note. ${ }^{*} \mathrm{p}<0.01 ;{ }^{*} \mathrm{p}<0.05$

When Table 3 was examined, a statistically significant difference was found between long-term accommodation place and leisure involvement sub-dimensions; attraction $(\mathrm{p}<$ $0.01)$, centrality $(p<0.01)$ and social bonding $(p<0.05)$. These differences were in the sub-dimension of attraction; between long-term accommodating in district and metropolitan, 
in the sub-dimension of centrality; between long-term accommodating in the village, province and metropolitan, in the sub-dimension of social bonding; between long-term accommodating in village and province.

Table 4. ANOVA test results according to daily leisure time

\begin{tabular}{|c|c|c|c|c|c|c|c|}
\hline Sub-dimensions & Daily leisure time & $\mathrm{n}$ & $\overline{\mathrm{X}}$ & Ss & $\mathrm{F}$ & $\mathrm{p}$ & Difference \\
\hline \multirow{4}{*}{ Attraction } & ${ }^{\mathrm{a}} 1-3$ hour & 46 & 2.74 & .91 & \multirow{4}{*}{.762} & \multirow{4}{*}{.408} & \multirow{4}{*}{-} \\
\hline & ${ }^{\mathrm{b}} 4-6$ hours & 35 & 3.00 & .94 & & & \\
\hline & ${ }^{\mathrm{c}} 7$ hours + & 25 & 2.95 & .91 & & & \\
\hline & Total & 106 & 2.87 & .92 & & & \\
\hline \multirow{4}{*}{ Centrality } & ${ }^{\mathrm{a}} 1-3$ hour & 46 & 3.46 & .78 & \multirow{4}{*}{2.575} & \multirow{4}{*}{$.020^{*}$} & \multirow{4}{*}{$a-b$} \\
\hline & ${ }^{\mathrm{b}} 4-6$ hours & 35 & 3.55 & .85 & & & \\
\hline & ${ }^{\mathrm{c}} 7$ hours + & 25 & 4.01 & .75 & & & \\
\hline & Total & 106 & 3.62 & .82 & & & \\
\hline \multirow{4}{*}{ Social Bonding } & ${ }^{\mathrm{a}} 1-3$ hour & 46 & 3.36 & .78 & \multirow{4}{*}{2.482} & \multirow{4}{*}{$.022 *$} & \multirow{4}{*}{$a-b$} \\
\hline & ${ }^{\mathrm{b}} 4-6$ hours & 35 & 3.42 & .83 & & & \\
\hline & ${ }^{\mathrm{c}} 7$ hours + & 25 & 3.89 & .76 & & & \\
\hline & Total & 106 & 3.51 & .82 & & & \\
\hline \multirow{4}{*}{ Identity Expression } & ${ }^{\mathrm{a}} 1-3$ hour & 46 & 3.47 & .89 & \multirow{4}{*}{1.184} & \multirow{4}{*}{.170} & \multirow{4}{*}{-} \\
\hline & ${ }^{\mathrm{b}} 4-6$ hours & 35 & 3.61 & .73 & & & \\
\hline & ${ }^{\mathrm{c}} 7$ hours + & 25 & 3.85 & .76 & & & \\
\hline & Total & 106 & 3.61 & .82 & & & \\
\hline \multirow{4}{*}{ Identity Affirmation } & ${ }^{a} 1-3$ hour & 46 & 3.39 & .90 & \multirow{4}{*}{1.284} & \multirow{4}{*}{.126} & \multirow{4}{*}{-} \\
\hline & ${ }^{b} 4-6$ hours & 35 & 3.62 & .75 & & & \\
\hline & ${ }^{\mathrm{c}} 7$ hours + & 25 & 3.77 & .53 & & & \\
\hline & Total & 106 & 3.56 & .79 & & & \\
\hline
\end{tabular}

Note. ${ }^{*} \mathrm{p}<0.05$.

When Table 4 was examined, a statistically significant difference was found between daily leisure time and leisure involvement sub-dimensions; centrality $(\mathrm{p}<0.05)$ and social bonding $(\mathrm{p}<0.05)$. These differences in the sub-dimension of centrality; between 1-3 hour and 4-6 hours, in the sub-dimension of social bonding; between 1-3 hour and 4-6 hours. 
Table 5. ANOVA test results according to doing sport

\begin{tabular}{|c|c|c|c|c|c|c|}
\hline Sub-dimensions & Doing Sport & $\mathrm{n}$ & $\overline{\mathrm{X}}$ & Ss & $\mathrm{t}$ & $\mathrm{p}$ \\
\hline \multirow{2}{*}{ Attraction } & Yes & 40 & 3.23 & .93 & \multirow{2}{*}{3.281} & \multirow{2}{*}{$.001^{*}$} \\
\hline & No & 66 & 2.66 & .84 & & \\
\hline \multirow{2}{*}{ Centrality } & Yes & 40 & 3.61 & .96 & \multirow{2}{*}{-.139} & \multirow{2}{*}{.889} \\
\hline & No & 66 & 3.63 & .73 & & \\
\hline \multirow{2}{*}{ Social Bonding } & Yes & 40 & 3.59 & .97 & \multirow{2}{*}{.838} & \multirow{2}{*}{.404} \\
\hline & No & 66 & 3.45 & .71 & & \\
\hline \multirow{2}{*}{ Identity Expression } & Yes & 40 & 3.58 & .80 & \multirow{2}{*}{-.312} & \multirow{2}{*}{.756} \\
\hline & No & 66 & 3.63 & .83 & & \\
\hline \multirow{2}{*}{ Identity Affirmation } & Yes & 40 & 3.51 & .92 & \multirow{2}{*}{-.490} & \multirow{2}{*}{.625} \\
\hline & No & 66 & 3.59 & .70 & & \\
\hline
\end{tabular}

Note. ${ }^{*} \mathrm{p}<0.01$.

When Table 5 was examined, a statistically significant difference was found in favor of doing sport in the sub-dimension of attraction $(\mathrm{p}<0.01)$. There were no differences in other sub-dimensions.

\section{Discussion}

In this section, the results of the analysis regarding whether there is a statistically significant difference between the variables of gender, age, long-term place of residence, daily leisure time and sporting status and leisure time involvement are discussed and interpreted.

A statistically significant difference was found between the gender variable and the social relationship sub-dimension of the participants in favor of women $(\mathrm{p}<0.05)$. This situation is thought to be because women have more social relations in daily life than men. Besides, the fact that men have a higher workload than this situation can explain women. When the related literature is reviewed (Wiley et al., 2000; Hardin \& Greer, 2009; Moccia, 2000) the gender variable was found to be one of the variables affecting the involvement of physical recreational activities.

According to participants' age and leisure involvement, there were not any significant differences $(\mathrm{p}>0.05)$. When different studies are examined, according to the study of Aydin (2016), there were significant differences between age and centrality sub-dimension of leisure involvement. These differences were between the ages of 20- and 21-30 in favor of 20 and younger participants. According to Aslan and Aslan Cansever (2012), the age of the individuals are playing an active role in participating in recreational activities. When the 
preferred recreational activities are examined, it is seen that as the age increases, the level of interest of the individuals to the activities changes as well.

According to analysis results, a statistically significant difference was found between long-term accommodation place and leisure involvement sub-dimensions; attraction $(\mathrm{p}<$ $0.01)$, centrality $(p<0.01)$ and social bonding $(p<0.05)$. When these sub-dimensions were examined, it was seen that people who leave in provinces or metropolitans participate in recreational activities more than people who leave in the villages and districts. We may explain this situation in two ways first; metropolitans or provinces are mostly stressing full for people, and that is why they need to refresh themselves by recreational activities. Second; when we compare with districts and villages provinces or metropolitans have more recreational facilities, and also it is easy to reach them.

According to analysis results, a statistically significant difference was found between daily leisure time and leisure involvement sub-dimensions; centrality $(\mathrm{p}<0.05)$ and social bonding $(\mathrm{p}<0.05)$. These differences were in the sub-dimension of centrality; between 1-3 hour and 4-6 hours, in the sub-dimension of social bonding; between 1-3 hour and 4-6 hours. It was seen that individuals who participate in leisure activities have good social relationships and pay much attention to participate in recreational activities. It shows that free time is an essential factor for individuals to establish social relationships (Türker et al., 2016; Özdağ et al., 2009).

According to analysis results, a statistically significant difference was found in favor of doing sport in sub-dimension of attraction $(\mathrm{p}<0.01)$. According to this result, we can say that sport has a vital role in directing individuals to recreational activities. According to the study of Terzioğlu and Yazıcı (2003) with university students, students stated that they consider free time and sport as a means of physical and mental development. Yeoman and Una (2004) reported that $61 \%$ of the people in Germany prefer sport as a leisure activity. They stated that the main reasons for the high rate of active participation in sporting activities in free time are due to the personal and social characteristics of the sport.

As a result, it was seen that the social relationships of the women participating in the study were higher in leisure time activities than men. It shows that long-term accommodation place affects an individual's leisure involvement status. It has been observed that recreational efficacy has a vital role in directing individuals to sports. According to results, we may say that the diversification of recreational facilities in rural areas will increase individuals' interest in recreational activities. According to results, we may say that the diversification of recreational facilities in rural areas will increase individuals' interest in recreational activities. When these results are evaluated, informing people about recreational activities and building sportive recreational areas will enable individuals to participate in more recreational activities.

\section{References}

Aslan, N., \& Aslan Cansever, B. (2012). Leisure Time Perception of Adolescents. Hacettepe University Journal of Education, 42, 23-25. 
Aydın, İ. (2016). Determining the level of interest and happiness of fitness participants towards recreational activities (Master Thesis, Institute of Health Sciences, Gazi University, Ankara).

Aydın, İ., \& Yaşartürk, F. (2016). Level of Engagement of Fitness Participants for Recreational Activities: Status According to Demographic Characteristics. International Journal of Science Culture and Sport, 4(Special Issue 3), 704-711. https://doi.org/10.14486/ IntJSCS617

Ayhan, C., Ekinci, N. E., Yalçın, İ., \& Yiğit, Ş. (2018). Investigation of Constraints that Occur during Participation in Leisure Activities by High School Students: A Sample of Turkey. Education Sciences, 8(2), 1-9. https://doi.org/10.3390/educsci8020086

Berlin, K., Kruger, T., \& Klenosky, D. B. (2018). A mixed-methods investigation of successful aging among older women engaged in sports-based versus exercise-based leisure time physical activities. Journal of Women \& Aging, 30(1), 27-37. https://doi.org/10.1080/ 08952841.2016 .1259439

Büyüköztürk, Ş. (2011). Data Analysis for Social Sciences (14 Baskı). Ankara: Pegem Akademi.

Chang, H. H. (2016). Gender Differences in Leisure Involvement and Flow Experience in Professional Extreme Sport Activities. World Leisure Journal, 59(2), 124-139. https://doi.org/ 10.1080/16078055.2016.1166152

Ekinci, N. E., Yalcin, I., \& Ayhan, C. (2019). Analysis of Loneliness Levels and Digital Game Addiction of Middle School Students According to Various Variables. World Journal of Education, 9(1), 20-27. https://doi.org/10.5430/wje.v9n1p20

Escaron, A. L., Vega-Herrera, C., Steers, N., Chung, J., Martinez, C., Hochman, M., \& Lara, M. (2019). Factors Associated With Leisure Time Physical Activity among Schoolchildren in a Predominantly Latino Community. Journal of School Health, 89(6), 444-451. https://doi.org/10.1111/josh.12755

Eskiler, E., \& Karataş, G. (2017). Investigating the Relationships between Leisure Time Behaviors and Behavioral Intentions of Sakarya University Students. Istanbul University Journal of Sport Sciences, 7(3), 10-24.

Gratton, C., \& Jones, I. (2010). Research methods for sports studies (2nd ed.). London: Routledge.

Gürbüz, B., Çimen, Z., \& Aydın, İ. (2015). Validity and Reliability Study of the Turkish Form of Leisure Involvement Scale. SPORMETRE Journal of Physical Education and Sport, 16(4), 256-265.

Hardin, M., \& Greer, J. D. (2009). the Influence of Gender-Role Socialization, Media Use and Sports Participation on Perceptions of Gender-Appropriate Sports. Journal of Sport Behaviour, 32(2), 207-226. 
Havitz, M. E., \& Dimanche, F. (1999). Leisure Involvement Revisited: Drive Properties and Padoxes. Journal of Leisure Research, 31, 122-149. https://doi.org/10.1080/00222216.1999. 11949854

Havitz, M. E., Kaczynski, A. T., \& Mannell, R. C. (2013). Exploring Relationships between Physical Activity, Leisure Involvement, Self-Efficacy, and Motivation via Participant Segmentation. Leisure Sciences: An Interdisciplinary Journal, 35(1), 45-62. https://doi.org/ 10.1080/01490400.2013.739890

Heo, J., Lee, Y., Pedersen, P. M., \& McCormick, B. P. (2010). Flow Experience in the Daily Lives of Older Adults: An Analysis of the Interaction between Flow Individual Differences Serious Leisure Location and Social Context. Canadian Journal, 29(3), 411-423. https://doi.org/10.1017/S0714980810000395

Keskin, U., \& Bayram, A (2018). Evaluation of Recreative Activitiesiln the Context of Classification of Consumer Products. Sportive Sight: Journal of Sport and Ecucation Science, Special Issue, 1, 1-13.

Kontogianni, E. (2011). Involvement and Loyalty in Recreation Swimming in Greece: Investigating Relationsips. International Journal of Sport Management, Recreation \& Tourism, 8, 13-34. https://doi.org/10.5199/ijsmart-1791-874X-8b

Kyle, G., Absher, J., Norman, W., Hammitt, W., \& Jodice, L. (2007). A Modified Involvement Scale. Leisure Studies, 26(4), 399-427. https://doi.org/10.1080/02614360600896668

Lee, J., \& Graefe, A. (2002). Psychological Commitment as a Mediator of the Relationship between Involvement and Loyalty (Tech. Report No. 289). Newtown: Northeastern Research Station.

Mansuroğlu, S. (2002). Determination of Mediterranean University Students' Choice of Outdoor Leisure Time. Journal of Akdeniz University Faculty of Agriculture, 15(2), 53-62.

Moccia, F. D. (2000). Planning Time: An Emergent European Pratice. European Planning Studies, 8(3), 367-376. https://doi.org/10.1080/713666408

Özdağ, S., Yeniçeri, M., Fişekçioğlu, İ. B., Akçakoyun, F., \& Kürkçü, R. (2009). Leisure time tendencies of civil servants, anthropometric and physical fitness levels. Selçuk University Journal of Social Sciences Institute, 22, 307-323.

Özkan, S. (2018). Investigation of the Factors Constructing Public Employees' Participation in Leisure Activities and Factors Facilitating Participation in Leisure Activities (Master Thesis, Institute of Health Sciences, Dumlupınar University, Kütahya).

Özşaker, M. (2012). A Study on the Reasons of Young People Not Participating in Leisure Activities. Selçuk University, Journal of Physical Education and Sports Science, 14(1), 126-131.

Tachis, S., \& Tzetzis, G. (2015). The Relationship among Fans' Involvement, Psychological Commitment, and Loyalty in Professional Team Sports. International Journal of Sport 


\section{Macrothink}

Management, Recreation \& Tourism, 18, 1-25. https://doi.org/10.5199/ijsmart-1791$874 \mathrm{X}-18 \mathrm{a}$

Terzioğlu, A., \& Yazıcı, M. (2003). Understanding Habits of University Students to Evaluate Free Time (Atatürk University Case). Journal of Erzincan Faculty of Education, 5(2), 1-31.

Türker, N., Ölçer, H., \& Aydın, A. (2016). Leisure Time Habits of Local People: The Case of Safranbolu. Karabuk University Journal of the Institute of Social Sciences, 6(1), 49-62. https://doi.org/10.14230/joiss230

Üstün, Ü. D., Kalkavan, A., \& Demirel, M. (2013). Investigating free time motivation scores of physical education and faculty of education students according to different variables. The Online Journal of Recreation and Sport, 2(1), 18-26.

Wiley, C. G. E., Shaw, S. M., \& Havitz, M. E. (2000). Men's and Women's Involvement in Sports: An Examination of the Gendered Aspects of Leisure Involvement. Leisure Sciences: An Interdisciplinary Journal, 22(1), 19-31. https://doi.org/10.1080/014904000272939

Yalçin, İ., Turğut, M., Gacar, A., \& Çalik, F. (2017). Investigation of Motivation of Female Athletes Studying at School of Physical Education and Sports According to Some Variables. International Journal of Cultural and Social Research, 3(Special Issue 2), 201-210.

Yeoman, I., \& Una, M. (2004). Sport and Leisure Operation Menagement. Thomson Learning, London.

Yetim, G. (2014). The Effect of Leisure Interest on Leisure Satisfaction and Loyalty: Research on Fitness Centers in Eskişehir (Master Thesis, Institute of Health Sciences, Anadolu University, Eskisehir).

\section{Copyright Disclaimer}

Copyright for this article is retained by the author(s), with first publication rights granted to the journal.

This is an open-access article distributed under the terms and conditions of the Creative Commons Attribution license (http://creativecommons.org/licenses/by/3.0/). 